ISSN: 2162-3104 Print/ ISSN: 2166-3750 Online

Volume 10, Issue S3 (2020), pp. 91-107

(C) Journal of International Students

https://ojed.org/jis

\title{
Exploring the Emotions of Single International Students in Hong Kong Facing the COVID-19 Pandemic
}

\section{Eksplorasi Emosi Mahasiswa Internasional Lajang di Hongkong dalam Menghadapi Pandemi COVID-19}

\author{
Suprihatin (Kehok) \\ Universitas Negeri Jakarta, Indonesia \\ Lilik Istiqomah \\ Institut Agama Islam Negeri (IAIN) Surakarta, Indonesia \\ Rini Intansari Meilani \\ Universitas Pendidikan Indonesia, Indonesia \\ Khoiriyah \\ Universitas Negeri Malang, Indonesia \\ Institut Agama Islam Negeri (IAIN) Jember, Indonesia
}

\begin{abstract}
This narrative study aims to explore the emotional experiences of international students in Hong Kong during the COVID-19 pandemic. Data in this study were garnered from the results of interviews with two single female students who were completing their doctoral studies at a public university in Hong Kong. We analyzed the interview data thematically with the Hargreaves's emotional geography framework (2001a, 2001b). Findings showed that the COVID-19 pandemic affected the emotional experience of international students in terms of the dissertation guidance process, psychological mental state, relationships with family, finance, and spirituality. This
\end{abstract}


empirical evidence may provide new insight into the role of emotionality in the completion of postgraduate studies during uncertain and worrying pandemic.

ABSTRAK: Penelitian ini bertujuan untuk mengeksplorasi pengalaman emosi mahasiswa internasional di Hongkong selama masa pandemi COVID-19. Data dalam penelitian ini diperoleh dari hasil wawancara terhadap dua mahasiswi lajang yang sedang menyelesaikan studi doktoral mereka. Data wawancara dianalisis secara tematik dengan kerangka pemikiran geografi emosi Hargreaves (2001a, 2001b). Hasil penelitian menunjukkan bahwa pandemi COVID-19 telah memengaruhi pengalaman emosi mahasiswa internasional dalam proses bimbingan disertasi, keadaan mental psikologis, hubungan dengan keluarga, finansial dan spiritualitas. Temuan ini diharapkan akan memberikan inspirasi tentang peran emosi dalam penyelesaian studi pascasarjana di masa pandemi yang tidak menentu dan mengkhawatirkan.

Keywords: COVID-19 pandemic, Emotional Geography, international students' experiences, narrative inquiry [pandemi COVID-19, Geografi Emosi, pengalaman mahasiswa internasional, penelitian naratif]

\section{PENDAHULUAN}

Sejak ditemukan pada akhir tahun 2019, COVID-19 menjadi kajian yang menarik bagi khalayak umum, termasuk para peneliti yang tertarik untuk mempelajari dampaknya terhadap beragam aspek kehidupan yang saling berkaitan seperti politik, kesehatan, ekonomi, sosial budaya dan pendidikan. Dalam konteks pendidikan, wabah COVID-19 ini sangat memengaruhi semua pembelajaran sekolah dan kegiatan akademik dan non-akademik kampus, termasuk mahasiswa asing yang sedang studi di berbagai belahan dunia. Misalnya, penelitian Ma, Heywood dan MacIntyre (2020) dalam konteks Australia menunjukkan bahwa mahasiswa sangat tergantung pada ketersediaan jaringan internet untuk berkomunikasi jarak jauh dengan dosen, pembimbing, keluarga dan teman. Keberadaan mereka menjadi sangat penting dalam membantu mengatasi beragam masalah kesehatan yang dialami oleh mahasiswa internasional pada masa pandemi.

Beragam isu kesehatan baik fisik maupun mental dan bahkan kasus bunuh diri ditemukan di Hongkong dalam masa pandemi ini (Choi, 2020; Lee, 2020). Hal ini disebabkan oleh pengaruh ditemukannya COVID-19 di Cina pada akhir tahun 2019. Dalam masa mencekam tersebut, banyak mahasiswa internasional yang belajar di Hongkong terkena dampaknya. Mereka harus bergelut dengan beragam isu yang mengancam keselamatan jiwa dan raganya. Oleh karena itu, mengupas salah satu sisi kehidupan mahasiswa asing di Hongkong yang sedang terdampak oleh pandemi COVID-19 menjadi sebuah daya tarik untuk dikaji secara empiris. Selain itu, masih terbatasnya penelitian yang berfokus pada emosi sebagai salah satu aspek psikologis yang berpengaruh pada kesuksesan studi mahasiswa di masa kritis.

Penelitian terdahulu berfokus pada mahasiswa internasional dan kesehatan (Chen, Akpanudo \& Hasler, 2020; Forbes-Mewett \& Sawyer, 2016), mahasiswa 
internasional dan pendidikan (Aydin, 2020; Haverila, Haverila \& McLaughlin, 2020), serta mahasiswa internasional dan motivasi belajar (Mostafa \& Lim, 2020). Penelitian sebelumnya juga masih terbatas dalam mengkaji refleksi diri tentang perjuangan mahasiswa internasional (Heng, 2020), gambaran deskriptif tentang mahasiswa internasional (Jing, Gosh, Sun \& Liu, 2020) dan kemampuan menyelesaikan belajar (Choudaha, 2020). Oleh karena itu, artikel ini menyajikan hasil studi naratif mengenai pengalaman emosi dua mahasiswi lajang asing yang berasal dari dua negara berbeda. Pengalaman emosi ini berkaitan dengan dampak drastis yang dialami oleh kedua mahasiswa internasional ini dalam kehidupan akademik dan non-akademik yang diakibatkan oleh prevalensi pandemi COVID-19.

\section{METODE}

\section{Konteks Penelitian}

Hongkong dipilih menjadi latar dalam penelitian ini karena kedua partisipan dalam penelitian ini, yang merupakan teman peneliti pertama, sedang menjadi mahasiswa di sana. Sejak bulan Januari tahun 2020, COVID-19 telah memasuki Hongkong dan kasus yang terkonfirmasi menunjukkan peningkatan (The Government of the Hong Kong Special Administrative Region, 2020). Dalam penelitian ini, desain penelitian naratif dipilih untuk mengeksplorasi kehidupan individu melalui penggalian informasi pengalaman pribadi serta bagaimana pengalaman tersebut terbentuk dan dimaknai secara kontekstual (Schreiber \& Asner-Self, 2011) yang akan memberikan wawasan untuk memahami dunia di sekitar kita (Webster \& Mertova, 2007). Dalam sebuah penelitian naratif, peneliti memiliki peran yang khas, yaitu sebagai kolaborator sekaligus partisipan (James, 2018). Dari awal pengumpulan sampai penyajian data dalam bentuk artikel ilmiah, peneliti naratif merupakan perpanjangan pemikiran dan perwakilan dari para partisipan yang ditelitinya. Karena perannya yang seperti ini, peneliti naratif harus selalu berhati-hati dalam menginterpretasi dan menyampaikan pemikiran partisipan.

Perekrutan partisipan dalam penelitian ini dilakukan berdasarkan prinsip kemudahan akses dan karakteristik partisipan yang sesuai dengan tujuan penelitian. Peneliti pertama adalah teman dari para partisipan yang bersedia untuk diwawancarai dalam penelitian ini. Mereka adalah Liong dan Astried (nama samaran) yang merupakan teman sekelas dalam beberapa mata kuliah pada tahun pertama program doktor. Hubungan pertemanan ini berlanjut sampai sekarang. Kami, peneliti pertama dan partisipan, sering berinteraksi secara sosial melalui aplikasi WhatsApp dan atau WeChat. Saat ini, Liong dan Astried berada pada tahun terakhir program doktor mereka. Liong adalah seorang perempuan lajang berkewarganegaraan Cina dan berusia sekitar 28 tahun. Astried adalah seorang perempuan lajang yang berkewarganegaraan Rusia dengan usia sekitar 30 tahun. 


\section{Pengumpulan Data}

Pengumpulan data dilakukan dengan wawancara melalui aplikasi Zoom dan pesan suara pada aplikasi WhatsApp. Kegiatan wawancara dilakukan oleh penulis pertama menggunakan bahasa Inggris. Sesuai dengan kesepakatan, wawancara dengan Liong dilakukan melalui pesan suara aplikasi WhatsApp pada tanggal 18 Juli 2020 selama 1 jam 30 menit. Tiga hari kemudian, pada tanggal 21 Juli 2020, wawancara dengan Astried dilakukan menggunakan aplikasi Zoom sesuai dengan sarannya selama 1 jam 30 menit. Pada saat wawancara, Astried menggunakan masker yang merupakan kewajiban bagi warga yang tinggal di Hongkong. Wawancara tambahan pada tanggal 16-17 Agustus 2020 dilakukan melalui pesan suara aplikasi WhatsApp untuk memperkaya data naratif. Pertanyaan yang diberikan kepada partisipan berfokus pada pengalaman emosinya mengenai dampak pandemi COVID-19 yang dialami dan dirasakan dalam berbagai aspek kehidupan.

\section{Analisis Data dan Kerangka Teori untuk Analisis}

Setelah wawancara selesai, langkah berikutnya adalah melakukan transkripsi data wawancara. Masing-masing anggota peneliti mendapatkan bagian yang sama dalam mentranskripsi data berdasarkan durasi waktu hasil wawancara. Selanjutnya, hasil transkripsi dibahas oleh tim peneliti dalam forum grup WhatsApp peneliti. Dalam proses transkripsi, salah satu peneliti mengalami kesulitan ketika mentranskrip data yang diperoleh dari Astried. Hal ini disebabkan oleh masker yang digunakan dan dialek yang terdengar kurang akrab bagi peneliti. Transkrip data utuh juga diberikan kepada masing-masing partisipan guna diperiksa kebenarannya. Kedua partisipan terkejut mendapatkan transkrip wawancara yang ternyata sampai sembilan halaman untuk Liong dan sebelas halaman untuk Astried.

Kerangka teori yang digunakan untuk menganalisis data dalam penelitian ini diadopsi dari teori geografi emosi yang dirumuskan oleh Hargreaves (2000, 2001a, 2001b, 2005). Teori ini terdiri atas lima dimensi emosi yang saling terkait yaitu geografi fisik/personal, geografi sosiokultural, geografi moral, geografi profesional dan geografi politik. Tabel 1 menjelaskan kelima dimensi tersebut. Data yang telah ditranskripsi dan diterjemahkan ke dalam bahasa Indonesia dianalisis secara tematik (Widodo, 2014) dengan mengidentifikasi pola yang muncul secara berulang dalam data. Identifikasi pola ini dihasilkan melalui proses pemberian kode pada kata/frasa/kalimat tertentu yang membentuk kategori atau topik tertentu yang mengacu pada teori geografi emosi. Dalam pemberian kode ini, proses identifikasi tema-tema yang relevan dengan mudah ditemukan. 
Tabel 1. Teori Geografi Emosi

\begin{tabular}{cl}
\hline Geografi emosi & \multicolumn{1}{c}{ Deskripsi konseptual } \\
\hline Geografi Fisik/Personal & Dimensi geografi ini memengaruhi interaksi sosial yang \\
& dibatasi oleh faktor-faktor, seperti kedekatan emosional yang \\
& terjadi dalam hubungan antara mahasiswa, dosen pembimbing \\
& dan masyarakat kampus lainnya. Jarak yang menunjukkan \\
& hubungan emosi ini sangat dipengaruhi oleh intensitas \\
& hubungan yang dilakukan oleh mahasiswa dan dosen \\
& pembimbing, misalnya. \\
& Dimensi ini menciptakan diskursus kedekatan atau \\
Geografi Sosiokultural & kesenjangan sosial dikarenakan oleh perbedaan ras, budaya, \\
& gender dan disabilitas, termasuk perbedaan cara merasakan \\
& dan mengekspresikan emosi yang dapat menciptakan jarak \\
& antar mahasiswa, dosen dan masyarakat kampus lainnya. Jika \\
& semua hal ini tidak dipahami secara sosial dan budaya, \\
& masyarakat kampus akan memperlakukan mahasiswa \\
& internasional berdasarkan stereotip yang ada atau norma \\
& sosial budaya masyarakat kampus dan masyarakat setempat. \\
& Diskursus kedekatan atau kesenjangan sosial dipengaruhi oleh \\
& nilai dan norma moral yang dimiliki oleh mahasiswa, dosen, \\
& dan masyarakat kampus lainnya dalam meraih visi dan tujuan \\
& yang kemungkinan berbeda antara satu dengan yang lainnya. \\
& Dalam dimensi ini, norma profesionalitas memengaruhi \\
& hubungan/interaksi sosial antara dosen, mahasiswa dan \\
Geografi Moral & masyarakat kampus lainnya. Setiap kampus memiliki norma- \\
& norma profesionalitas yang harus dipatuhi/dikuti oleh \\
& masyarakat kampus, termasuk mahasiswa internasional. \\
& Dalam dimensi ini, kekuasaan hierarki atau power \\
& menyebabkan kedekatan atau kesenjangan sosial di kalangan \\
& masyarakat kampus. Misalnya, otoritas kampus memiliki \\
& kekuasaan dalam mengendalikan masyarakat kampus, \\
& termasuk pemberlakuan kebijakan pembelajaran daring untuk \\
& dosen dan mahasiswa. \\
Geografi Profesional & \\
Geografi Politik &
\end{tabular}

\section{TEMUAN DAN PEMBAHASAN}

Penelitian ini dirancang untuk mengeksplorasi pengalaman emosi dua mahasiswi internasional lajang yang sedang menyelesaikan program doktor mereka dalam masa pandemi COVID-19 di Hongkong. Berdasarkan hasil analisis, diketahui bahwa kondisi tersebut memengaruhi pengalaman emosi mereka dalam lima hal. Kelima hal tersebut adalah proses bimbingan disertasi, keadaan mental psikologis, hubungan dengan keluarga, finansial dan spiritualitas. Pada bagian di bawah ini, tema yang teridentifikasi tersebut disajikan bersamaan dengan data yang mendukung. 


\section{Geografi Profesional: "Saya merasa kurang nyaman saat pertama konsultasi dengan menggunakan Zoom, tapi kemudian semua berubah"}

Liong dan Astried mengatakan bahwa mereka merasa cukup nyaman dalam berinteraksi dan berkonsultasi dengan pembimbing akademik secara langsung bertatap muka di kampus. Kegiatan konsultasi ini berjalan dengan lancar sebab semua elemen di kampus cukup mendukung, seperti keberadaan perpustakaan yang buka sepanjang waktu, kenyamanan membaca dan mengunduh semua dokumen yang dibutuhkan. Hal ini kemudian secara drastis berubah total saat pandemi berlangsung. Waktu itu peneliti pertama bertanya kepada Liong tentang bentuk konsultasi yang diterapkan oleh pembimbingnya. Liong menceritakan bahwa sejak pandemi dia melakukan proses bimbingan menggunakan aplikasi Zoom.

Dari wawancara yang mendalam terkuak satu hal penting yang dirasakan baik oleh Liong maupun Astried yaitu perasaan mereka pertama kali berkonsultasi memakai media Zoom. Di Cina, sudah menjadi hal umum bahwa setiap warga masyarakat termasuk mahasiswa dilarang memakai produk-produk teknologi dari luar Cina seperti Google, Facebook dan WhatsApp (Chiu, 2020). Aplikasi Zoom juga belum pernah digunakan oleh kedua partisipan dalam berkonsultasi dengan pembimbingnya. Saat pertama kali menggunakannya, mereka merasa khawatir dan canggung dalam mengekspresikan ide-ide yang dimiliki. Seiring waktu, Liong dan Astried menikmati konsultasi dengan pemanfaatan aplikasi tersebut. Sensasi yang dirasakan ketika pertama kali dan selanjutnya menggunakan Zoom tentu berbeda dengan konsultasi secara langsung. Hal ini kemungkinan disebabkan oleh perbedaan gaya berkomunikasi yang dipengaruhi oleh kebudayaan para partisipan dan pembimbing mereka, seperti dalam penelitian Nieto (2016). Hal tersebut membuat kedua partisipan kurang nyaman berkomunikasi melalui aplikasi Zoom.

Liong bercerita bahwa pada awalnya dia mengirimkan surel yang berisi permintaan untuk berkonsultasi dengan pembimbingnya. Ketika pembimbingnya menyatakan bersedia, maka mereka berdua akan menentukan waktu yang disepakati untuk bertemu melalui Zoom. Pembimbingnya kemudian mengirimkan sebuah tautan Zoom yang telah diatur sesuai waktu yang telah disepakati. Liong yang semula merasa khawatir, gugup dan bingung harus melakukan apa saat bertemu dengan pembimbingnya, dia mulai merasa nyaman seiring waktu. Selanjutnya, baik Liong maupun pembimbingnya sepakat untuk saling berdiskusi melalui Zoom pada masa pandemi ini. Sangat berbeda dengan Astried yang walaupun merasa nyaman menggunakan aplikasi Zoom, dia masih membutuhkan bimbingan secara tatap muka. Berikut kutipan wawancara dengan Liong dan Astried:

Ya.. sebenarnya pertama saya merasa khawatir bagaimana konsultasi lewat Zoom. Ini pertama kali bagi saya melakukannya. Saya mengirimkan permintaan berkonsultasi kepada pembimbing saya lewat email. Kemudian jika dia menyetujui permintaan saya, maka ia akan mengirim satu tautan Zoom untuk proses bimbingan. Pada hari yang telah disepakati, saya 
mengklik tautan tersebut dan mulailah kami berdiskusi. Saya merasa nyaman dan mudah. Untuk selanjutnya kami akan memakai Zoom terus. Lebih nyaman bagi kami, karena saya tidak perlu keluar rumah dan dia juga tidak perlu jauh-jauh datang ke kampus. (Liong, Wawancara WhatsApp,18 Juli 2020)

Berbeda, proses bimbingan yang saya lakukan sekarang menggunakan aplikasi Zoom. Dulu sih lebih nyaman, saya bisa bimbingan secara langsung tapi sekarang....harus pake Zoom. Memang mudah tetapi saya masih perlu pertemuan langsung seperti dulu. Pake Zoom tidak begitu bebas mengekspresikan apa yang saya pikirkan. (Astried, Wawancara Zoom, 21 Juli 2020)

Dari pernyataan Liong di atas dapat dimengerti bahwa ada perasaan khawatir akan kenyamanan berkonsultasi dengan menggunakan media Zoom untuk pertama kali. Dia merasa khawatir akan adanya interaksi yang kurang dan juga ketidakleluasaan dalam menyampaikan pendapat. Namun demikian, kekhawatiran itu sirna setelah dia mulai terbiasa berkonsultasi melalui Zoom. Jadi, walaupun ada rasa khawatir ketika mulai berkonsultasi melalui Zoom, Liong tetap profesional untuk terus menggunakan aplikasi tersebut sampai dia menemukan kenyamanan. Lain halnya dengan Astried, dia memang menemukan kenyamanan saat proses bimbingan menggunakan aplikasi Zoom, tetapi dia masih memerlukan pertemuan secara tatap muka.

\section{Geografi Sosiokultural: "Meskipun saya lajang dan sendiri di Hongkong, tapi saya tidak merasa kesepian"}

Kedua partisipan dalam penelitian ini adalah mahasiswi tingkat akhir yang sedang menyelesaikan studi doktoral mereka. Sejak tahun pertama, mereka hidup sendiri tanpa ditemani oleh keluarganya. Mereka berdua adalah mahasiswi dewasa yang mandiri dan bisa bertahan di tengah badai kesendirian ketika bencana sosial dan wabah COVID-19 melanda Hongkong. Lain halnya dengan mahasiswa doktoral yang membawa keluarga mereka, keseharian mahasiswa yang membawa keluarga lebih hangat dibanding dengan mahasiswa lajang. Bila mahasiswa yang membawa keluarga bisa bertukar cerita atau sekadar berbagi canda gurau dengan suami/istri dan juga anak-anaknya, mahasiswa lajang menjalani semuanya sendiri.

"Mendekatkan yang jauh" adalah metafora yang paling bermakna berkaitan dengan fungsi teknologi bagi kedua partisipan dalam studi naratif ini. Mendukung apa yang disampaikan oleh Ma, Heywood dan MacIntyre (2020), partisipan dalam studi ini juga sangat tergantung akan keberadaan teknologi untuk selalu merasa dekat dengan keluarga mereka. Teknologi membantu mereka mengatasi kerinduan pada keluarga dan orang tersayang. Dengan menggunakan teknologi, Liong merasa tidak ada yang berbeda dengan hari-hari sebelum pandemi. Intensitas komunikasi yang dia lakukan dengan kekasih dan keluarganya terbilang tinggi sehingga rasa rindunya terlampiaskan. Fasilitas 
komunikasi daring membuat jarak terasa tidak ada bagi Liong, sehingga tidak lagi menjadi masalah yang membebani secara fisik dan psikologis. Data berikut mendukung keterangan Liong:

Saya berkomunikasi dengan kekasih saya setiap hari, juga melalui videochat. Kami dapat melihat satu-sama lain. Sayapun melakukannya dengan ayah saya, paman, dan bibi. Dan ketika kami dapat melihat dan berbicara dengan satu sama lain, terkadang saya lupa karena mereka terasa bersama dengan saya dan saya baik-baik saja. (Liong, Wawancara WhatsApp, 18 Juli 2020)

Demikian juga halnya dengan Astried, kekecewaannya karena tidak bisa pulang di masa musim panas ini tergambar jelas dari jawaban atas pertanyaan "Apakah kaтu merindukan keluargamu?" Karena kebijakan jarak sosial yang sangat ketat di Hongkong, dia tidak bisa pergi terlalu jauh dari tempat tinggalnya di kampus. Dia tidak bisa bertemu dengan teman-temannya sebagai pengalihan rasa rindu kepada keluarganya. Tidak ada lagi tempat makan bersama lebih dari tiga orang. Selain itu, tempat duduk harus berjauhan atau berjaga jarak. Petugas keamanan dan petugas kantin kampus selalu siap sedia menegur siapa pun yang melanggar aturan ini. Berikut ungkapan Astried:

Sekarang bangku dan meja di kantin mulai berkurang, bagaimana saya bisa mengobrol dengan teman saya, setiap kali kami berdekatan petugas kantin datang menegur, di luar juga, satpam datang ngomong dengan bahasa Hongkong menyuruh kami tidak bergerombol padahal kan saya pengen curhat juga ke teman dekat saya. Saya memang lebih sering ngobrol dengan orang tua saya di Rusia, (menahan nafas) saya tidak bisa pulang ke Moscow, biasanya saya dan keluarga saya liburan bareng di Moscow, ya...telpon saja. (Astried, Wawancara Zoom, 21 Juli 2020)

\section{Geografi Politik: "Meski berat menanggung beban finansial, saya tetap terus mencari pekerjaan di tengah ketidakpastian ini"}

Pandemi memang memengaruhi segala lini kehidupan, tak terkecuali dari sisi ekonomi. Imbas pandemi pada sisi ini juga dirasakan oleh partisipan kami. Hal itu diungkapkan oleh Astried ketika ditanya tentang pekerjaannya sebagai asisten riset di kampus. Dengan segera, Astried menjawab bahwa dia sudah tidak menjadi asisten riset lagi tetapi sebagai guru bagi mahasiswa yang kesulitan dengan bahasa Inggris mereka. Lebih lanjut Astried menjelaskan bahwa dia tetap harus mencari pekerjaan tambahan untuk menopang keuangannya sebab dia sudah tidak menerima uang beasiswa lagi dan gaji yang dia terima dari pekerjaannya saat ini tidaklah cukup. Berikut kutipan wawancara dengan Astried:

Ee...tidak juga. Saya harus mencari beberapa kerja tambahan lagi di luar. Saya tidak bisa pergi sebab selama musim panas kemarin ada pembatasan. Saya juga tidak bisa pergi ke kampus. Tapi selama musim panas saya bisa 
pergi jalan-jalan keluar. Saya berusaha mencari kerja sampingan, beberapa pekerjaan mudah sebenarnya, tapi saya tidak bisa menemukan pekerjaan tersebut. Walaupun tidak mudah, saya tetap berusaha untuk mendapatkannya. (Astried, Wawancara Zoom, 21 Juli 2020)

Astried bercerita bahwa selama musim panas ada pembatasan yang disebabkan oleh adanya pandemi di Hongkong. Dia tidak bisa mendapatkan pekerjaan di kampus karena ditutup sehingga dia mencari pekerjaan di luar. Akan tetapi, pekerjaan paling mudah dan ringan pun sulit didapatkan karena identitasnya sebagai orang Rusia. Dengan kulit putih dan wajah Rusianya, dia bahkan kesulitan untuk mendapatkan pekerjaan yang dinilainya mudah (tidak sesulit menjadi asisten riset). Hal ini kemungkinan juga disebabkan oleh keadaan warga Hongkong sendiri yang menjadi pengangguran (Cheung, Fong \& Bressington, 2020) sehingga semua pekerjaan yang ada lebih diutamakan untuk warga Hongkong. Walaupun demikian, dia tetap berusaha untuk mendapatkan pekerjaan sampingan sebagai pendukung keuangannya. Keadaan kekurangan dana yang dialami oleh Astried banyak pula dialami oleh mahasiswa lainnya, bahkan sangat memengaruhi keberlanjutan program doktoral yang sedang diikuti oleh para partisipan, seperti dalam penelitian Laufer dan Gorup (2018). Dalam kekurangan yang sedang dialaminya, Astried berusaha untuk tetap bertahan menyelesaikan program doktoralnya.

Lain halnya dengan Liong, dalam masa pandemi ini, dia diterima bekerja di sebuah universitas di daerah kelahirannya dan mendapatkan kontrak kerja secara daring. Selama masa pandemi, dia tidak harus hadir secara fisik ke tempat kerjanya, tetapi tetap mendapatkan gaji. Liong mendapatkan pekerjaan dan gaji tersebut tanpa harus bersusah payah. Dia hanya perlu menandatangani kontrak kerja tersebut secara daring, dan dia mendapatkan gaji setiap bulan tanpa harus melakukan pekerjaan apapun, seperti pernyataan Liong berikut:

Kamu tau kabar menggembirakan apa yang saya dapatkan (dalam masa pandemi ini)? Saya mendapatkan pekerjaan di universitas dimana saya tinggal (di kampung halamannya di Cina). Universitas tersebut tidak memiliki pegawai yang memiliki gelar PhD dari luar negeri. Jadi mereka menawarkan pekerjaan pada saya dan karena mereka khawatir saya tidak akan kembali ke kampung halaman dan tidak menerima pekerjaan itu mereka mengirimkan kontrak kerja secara daring dan meminta saya untuk menandatanganinya. Saya tidak perlu melakukan pekerjaan apapun tapi saya digaji. (Liong, Wawancara WhatsApp,18 Juli 2020)

\section{Geografi Fisik: "Saya merasa kuat meski di sekitar saya orang-orang banyak yang depresi"}

"Studiku adalah hal yang terpenting bagiku". Itulah yang diucapkan para partisipan untuk menafikan segala hal yang membuat mereka terganggu secara kognitif maupun emosional sebagai mahasiswi internasional lajang. Astried misalnya, dia merasa pembatasan fisik dan sosial dalam masa pandemi COVID- 
19 begitu membebani secara psikologis dan sosiokultural karena membatasi geraknya dalam berinteraksi. Sedangkan bagi Liong, dia menyatakan bahwa lebih aman dan nyaman bagi dirinya untuk tetap tinggal di rumah susun (apartemen). Dia melakukan ini untuk menghindari hal-hal yang tidak diinginkan, seperti bertemu dengan banyak orang atau terinfeksi virus corona yang mungkin bersumber dari barang-barang yang dibeli ketika berbelanja secara luring. Itulah sebabnya mengapa Liong lebih memilih untuk berbelanja secara daring yang dirasa lebih aman. Berikut adalah kutipan wawancara dengan Liong dan Astried:

Untuk saya sendiri, seperti yang saya katakan padamu, saya tetap tinggal di flat yang membuat saya nyaman dan merasa aman. Saya merasa khawatir ketika saya keluar untuk membeli bahan makanan atau sekedar jalan-jalan sebab saya takut apakah barang-barang tersebut aman (dari virus)? seberapa banyak saya akan berhubungan dengan banyak orang. Nah hal-hal semacam itu yang membuat saya merasa tidak nyaman. Jadi, bagi saya mengisolasi diri lebih baik dan lebih aman. (Liong, Wawancara WhatsApp, 18 Juli 2020)

\begin{abstract}
Sangat membosankan. Saya tidak tahu apa yang harus saya lakukan. Seperti tidak tau apa yang harus dilakukan untuk menghibur dirimu sendiri. Saya tidak dapat pergi keluar terlalu sering. Saya tidak bisa pergi ke restoran atau menonton film di bioskop. Dan saya pun merasa takut untuk keluar dan terkadang harus berfikir dua kali sebelum pergi keluar. Apakah saya harus pergi atau tidak. Jadi sangat membosankan. Jadi saya berusaha untuk menghibur diri saya dan menerima semua kebosanan ini, dengan melakukan hal yang bisa menghibur saya di rumah dengan hal-hal yang bisa dilakukan seperti menonton film yang bisa diputar di rumah. (Astried, Wawancara Zoom, 21 Juli 2020)
\end{abstract}

Pembatasan secara fisik pada umumnya akan menyebabkan terganggunya kesehatan mental (Cao, Fang, Hou, Han, Xu, Dong \& Zheng, 2020; Dubey, Biswas, Ghosh, Dubey, Chatterjee, Lahiri \& Lavie, 2020; Mechili, Saliaj, Kamberi, Girvalaki, Peto, Patelarou, Bucaj \& Patelarou, 2020). Hal ini dirasakan oleh Astried sebagai sebuah beban psikologis yang besar karena kebutuhan berinteraksi dengan orang lain tidak dapat terpenuhi. Astried merasa sangat bosan karena dia bingung dengan apa yang harus dilakukan untuk menghibur dirinya dalam kesendirian. Di satu sisi, dia merasa bosan karena tidak dapat keluar meskipun hanya untuk makan sejenak di restoran atau menonton di bioskop. Di sisi lain, dia merasakan ketakutan jika harus keluar rumah. Dilema ini membuat Astried semakin tertekan dalam kebosanan sehingga dia berusaha untuk menghibur dirinya sendiri dengan aktivitas yang dapat dilakukan di rumah seperti menonton film.

Kondisi yang semakin memperkuat dilema yang dihadapi Astried adalah pola komunikasi yang terbentuk dari latar budayanya (Lim, 2016). Sebagai orang Rusia, dia terbiasa berbicara hanya pada orang terdekatnya saja, terutama dengan orangtuanya walaupun hanya sesekali saja ketika ditelepon. Seiring 
waktu, beban psikologis yang ia hadapi membuatnya menjadi semakin tegar dan berpikir pragmatis. Sebagai pembelajar dewasa di tahun terakhir masa pendidikan, dia merasa harus segera menyelesaikan studinya agar dapat kembali ke Rusia bertemu dengan keluarga yang sangat dia rindukan. Bagi Astried, saat ini tidak ada yang ideal yang bisa didapatkan ataupun dilakukan, semuanya dalam kondisi yang tidak mengenakkan. Semua gejolak pertempuran rasa dan pikir yang dialami menggiringnya untuk "menerima", menjalani dengan penuh rasa syukur, dan mengatur strategi untuk mencapai tujuan utamanya. Dalam wawancara yang dilakukan, Astried menunjukkan keyakinannya dengan mengulang-ulang kata "menerima" sebagai penegasan bahwa dia memiliki tekad yang sangat kuat dari dalam jiwanya dengan apa yang dia katakan dan lakukan. Berikut kutipannya:

Menerima...menerima....seperti menerima semua hal ini sudah terjadi dan banyak-banyak bersyukur karena banyak orang dalam keadaan yang buruk saat ini dan saya berfikir saya tidak dalam keadaan seburuk itu. Saya merasa cukup diberkati karena saya memiliki banyak fasilitas. Tinggal di dalam kampus tidak terlalu buruk. Kita tidak jalan-jalan tapi masih bisa keluar dari ruangan dengan menerapkan beragam aktivitas pencegahan dengan mencuci tangan, mencuci baju yang dipakai setiap hari, dan menggunakan masker. Universitas kami memberikan kami satu masker setiap hari dan ini merupakan hal yang bagus karena jika tidak saya akan menghabiskan banyak uang hanya untuk membeli masker. Bagi saya saat ini yang paling penting adalah menyelesaikan studi saya dan pulang bertemu dengan keluarga saya yang saya sangat rindukan. (Astried, Wawancara Zoom, 21 Juli 2020)

Dari pernyataan di atas, sangat jelas bahwa Astried akhirnya menerima segala hal yang terjadi dan beradaptasi serta bersyukur dengan apa yang dimiliki. Bertempat tinggal di kampus menjadi strategi hidup yang baik menurutnya, selain mendekatkan dia secara psikologis pada tujuan akademiknya. Beragam fasilitas yang didapatkan menjadi daya tarik tersendiri ketika Astried bersyukur. Hal ini Astried lakukan untuk mengatasi tekanan psikologis (kesendirian dan kebosanan) yang dialami dalam masa pandemi. Dia bernegosiasi dengan lingkungannya sehingga terjadi keseimbangan emosi dalam dirinya. Semua ini Astried lakukan untuk mencapai tujuan yang sangat diinginkannya yaitu lulus dan pulang ke Rusia.

Berbeda dengan Astried, Liong merasa menghadapi tekanan emosional yang lebih besar karena identitasnya sebagai warga negara Cina yang selalu dihubungkan sebagai penyebab terjadinya pandemi. Selain itu, pemerintah dan pihak universitas di Hongkong pun mulai memberlakukan pembatasan sosial yang ketat. Liong membaca dan mengikuti berita yang ditayangkan di televisi maupun situs-situs berita bahwa banyak sekali terjadi gangguan sosial di Hongkong. Orang-orang merasa tidak aman dan tidak nyaman bahkan hanya sekadar membeli kebutuhan pokok ataupun jalan-jalan. Hal ini terus-menerus terjadi berbulan-bulan sehingga membuat sebagian masyarakat mengalami sakit 
mental, tekanan psikologis dan juga emosi yang tidak stabil. Liong tidak menghitung secara pasti berapa banyak masyarakat yang mengalami hal ini, tetapi dia menegaskan bahwa cukup banyak anggota masyarakat yang mengalami depresi (Choi, 2020; Lee, 2020). Berikut pernyataan Liong:

Saya mengikuti berita bahwa banyak masyarakat yang mengalami gangguan sosial, antara lain merasa tidak aman dan tidak stabil lingkungan sosialnya. Hal ini mempengaruhi banyak orang sehingga mereka merasakan sakit mental, psikologi dan emosi. Saya tidak ingat berapa banyak jumlahnya, tetapi sedikit banyak dari masyarakat ini mengalami depresi.

Tapi saya sekarang berhenti membaca berita itu, saya tidak perlu berita itu.

(Liong, Wawancara WhatsApp, 16 Agustus 2020)

Karena Cina terpapar oleh COVID-19 terlebih dahulu dibandingkan negara lain, Liong merasa sudah teruji. Dalam kesendirian tanpa keluarga, dia dituntut untuk mampu tetap waras dalam berpikir dan bertindak sehingga dia bisa tetap sehat dan bisa melanjutkan studinya dengan lancar. Berdasarkan cerita Liong tersebut, dapat disimpulkan bahwa Liong bisa menghadapi berbagai kesulitan selama masa pandemi. Bahkan, dia berhasil untuk tetap kuat menjaga kewarasan berpikir dan kesehatannya di antara orang-orang yang depresi di tengah pandemi COVID-19 dan demonstrasi.

Liong dan Astried yang lajang dan sendiri berada di perantauan terbukti tetap bisa kuat menghadapi kesulitan. Kedua partisipan dalam penelitian ini memiliki cara tersendiri dalam menghindari depresi dan gangguan kesehatan mental lainnya. Astried berusaha menerima apa yang terjadi dan membandingkan apa yang dimilikinya dengan apa yang tidak dimiliki orang lain. Sementara itu, Liong menghentikan kebiasaannya membaca berita yang kemungkinan akan memengaruhi kesehatan mentalnya.

\section{Geografi Moral: "Kudekati TUHAN dalam kamar sempitku"}

Sebagian besar orang Indonesia meyakini bahwa warga negara dari negara berpaham komunis pasti tidak beragama (ateis), seperti Cina dan bekas Uni Soviet, Rusia (Hafidhuddin, 2017). Tetapi, dalam studi ini, para peneliti mendapati kenyataan bahwa kedua partisipan meyakini adanya Tuhan. Liong sering mengunjungi wihara dan tempat ibadah agama Buddha lainnya bersama peneliti pertama ketika dia masih di Hongkong. Hal tersebut menunjukkan hati dan perilaku Liong yang percaya kepada Tuhan ketika berada di Hongkong, perilaku yang tidak pernah dilakukan ketika dia berada di Cina Daratan. Sementara itu, Astried yang seorang Kristen Ortodoks merayakan Natal setiap tanggal 6 Januari dan hanya pergi ke Gereja di saat itu saja.

Kondisi spiritual kedua partisipan tersebut menarik karena di masa pandemi ini Liong tidak bisa pergi ke wihara, sedangkan Astried tidak bisa pulang ke negaranya untuk merayakan Natal dan pergi ke gereja. Hal ini mendorong kedua partisipan untuk lebih sering mendekat kepada Tuhan. Liong berdoa di kamarnya dan sesekali memandang patung Dewi Kuan Im yang 
terlihat jelas dari jendela kamar walaupun letaknya jauh. Sementara itu, Astried berdoa sambil bermeditasi dalam yoga. Kedua cara partisipan mendekatkan jiwa mereka kepada Tuhan yang diyakini tidak jauh berbeda. Hal ini berbeda dengan yang ditemukan oleh Bryson, Andres dan Davies (2020) di mana para partisipan dalam penelitian mereka melakukan ibadah secara daring. Berikut kutipan pernyataan Liong dan Astried:

Selama pandemik saya tidak bisa pergi ke mana-mana walaupun saya ingin pergi. Pertama karena pemerintah melarang kami pergi ke manapun, kedua bahkan bila situasi sudah bagus pun kami tidak bisa pergi dengan bebas karena saya rasa tetap tidak aman selama musim pandemik ini. Ya, saya tidak bisa pergi ke tempat ibadah, saya hanya berdoa pada Tuhan saya di ruangan saya. Dewi Kuan Im selalu ada di depan sana. (Liong, Wawancara WhatsApp, 17 Agustus 2020)

"Saya tidak pergi ke gereja... saya hanya berdoa di rumah dan dalam hati saya saja". (Astried, Wawancara WhatsApp, 17 Agustus 2020)

\section{KESIMPULAN}

Penelitian ini sangat penting dilakukan karena masih kurangnya informasi dan pengetahuan mengenai cara mahasiswi internasional lajang beradaptasi selama masa krisis pandemi. Peneliti menyadari adanya keterbatasan dalam penelitian ini, seperti partisipan yang hanya mewakili gender tertentu dan sumber data yang terbatas. Penelitian selanjutnya bisa melibatkan berbagai gender dan sumber data lainnya yang akan menambah warna dan kompleksitas narasi. Para peneliti menyimpulkan bahwa partisipan mampu beradaptasi dengan baik ketika menghadapi masa yang sulit di Hongkong. Hasil penelitian ini diharapkan dapat memberikan tambahan wawasan dan informasi akademik dan non-akademik, khususnya bagi calon mahasiswa Indonesia lajang yang akan belajar ke luar negeri.

\section{Deklarasi Penulis [Disclosure Statement]}

Penulis menyatakan bahwa tidak ada konflik kepentingan dalam hal riset, kepengarangan, dan publikasi artikel ini. [The authors declared no potential conflicts of interest with respect to the research, authorship, and/or publication of this article.]

\section{Pernyataan Kontribusi Penulis [Authors' Contribution Statements]}

Suprihatin (Kehok): Mengonsep ide (utama), metode penelitian (setara), menulis draf artikel awal (setara), mengedit (utama), referensi (utama), proofreading (penguat) [Conceptualization of ideas (lead), methodology (equal), first drat (equal), editing (lead), referencing (lead), proofreading (supporting)]; Lilik Istiqomah: Mengonsep ide (penguat), metode penelitian (setara), menulis draf artikel awal (setara), mengedit (penguat), referensi (penguat), proofreading (utama) [Conceptualization of ideas (supporting), methodology (equal), first draft (equal), editing (supporting), referencing (supporting), proofreading (lead]; Rini Intansari Meilani: Mengonsep ide (penguat), metode penelitian (setara), menulis draf artikel awal (setara), mengedit (penguat), referensi (penguat), proofreading (penguat) [Conceptualization of ideas (supporting), 
methodology (equal), first draft (equal), editing (supporting), referencing (supporting), proofreading (supporting)]; Khoiriyah: Mengonsep ide (penguat), metode penelitian (setara), menulis draf artikel awal (setara), mengedit (penguat), proofreading (penguat) [Conceptualization of ideas (supporting), methodology (equal), first draft (equal), editing (supporting), proofreading (supporting)].

\section{DAFTAR REFERENSI}

Aydin, O. T. (2020). Social interaction between students: Local and international experiences at a Turkish university. Journal of International Students, 10(2), 383-400. DOI: 10.32674/jis.v10i2.1067

Bryson, J. R., Andres, L., \& Davies, A. (2020). COVID-19, virtual church services and a new temporary geography of home. Journal of Economic and Social Geography, 111(3), 360-372. DOI: 10.1111/tesg.12436

Cao, W., Fang, Z., Hou, G., Han, M., Xu, X., Dong, J., \& Zheng, J. (2020). The psychological impact of the COVID-19 epidemic on college students in China. Psychiatry Research, 287, 112934. DOI: 10.1016/j.psychres.2020.112934

Chen, H., Akpanudo, U., \& Hasler, E. (2020). How do Chinese international students view seeking mental health services. Journal of International Students, 10(2), 286-305. DOI: 10.32674/jis.v10i2.765

Cheung, T., Fong, T. K. H., \& Bressington, D. (2020). COVID-19 under the SARS cloud: Mental health nursing during the pandemic in Hong Kong. Journal of Psychiatric Mental Health Nursing. Terbit pertama online (hlm. 1-3). DOI: 10.1111/jpm.12639

Chiu, K. (2020). Facebook and Google, banned in China, enjoy unrivalled popularity in Hong Kong. Diakses tanggal 26 Agustus 2020, https://www.scmp.com/abacus/culture/article/3092364/facebook-and-googlebanned-china-enjoy-unrivalled-popularity-hong

Choudaha, R. (2020). Addressing the affordability crisis for international students. Journal of International Students, 10(2), iii-v. DOI: 10.32674/jis.v10i2.1969

Choi, T. (2020). Students suicide in Hong Kong needs attention, even amid coronavirus pandemic and political unrest. Diakses tanggal 14 Agustus 2020, https://www.scmp.com/comment/letters/article/3089723/student-suicidehong-kong-needs-attention-even-amid-coronavirus

Dubey, S., Biswas, P., Ghosh, R., Dubey, M. J., Chatterjee, S., Lahiri, D., \& Lavie, C. J. (2020). Psychosocial impact of COVID-19. Diabetes \& Metabolic Syndrome: Clinical Research \& Reviews, 14, 779-788. DOI: 10.1016/j.dsx.2020.05.035

Forbes-Mewett, H., \& Sawyer, A. M. (2016). International students and mental health. Journal of International Students, 6(3), 661-677.

Hafidhuddin, D. (2017). Indonesia menolak ateisme [Indonesia rejects atheism]. $\begin{array}{llll}\text { Diakses } & \text { tanggal } & 25 & \text { Agustus }\end{array}$ https://republika.co.id/berita/ox3cwg396/indonesia-menolak-ateisme

Hargreaves, A. (2000). "Mixed emotions: Teachers' perception of their interaction with students." Teaching and Teacher Education, 16(8), 811-826. DOI: 10.1016/S0742-051X(00)00028-7 
Hargreaves, A. (2001a). Emotional geographies of teaching. Teachers College Record, 103(6), 1056-1080. DOI: 10.1111/0161-4681.00142

Hargreaves, A. (2001b). The emotional geographies of teachers' relations with colleagues. International Journal of Educational Research, 35(5), 503-527. DOI: 10.1016/S0883-0355(02)00006-X

Hargreaves, A. (2005). Educational change takes ages: Life, career and generational factors in teachers' emotional responses to educational change. Teaching and Teacher Education, 21(8), 967-983. DOI: 10.1016/j.tate.2005.06.007

Haverila, M. J., Haverila, K., \& McLaughlin, C. (2020). Variables affecting the retention intentions of students in higher education institutions: A comparison between international and domestic students. Journal of International Students, 10(2), 358-382. DOI: 10.32674/jis.v10i2.1849

Heng, T. T. (2020). "Chinese themselves are changing": Why we need alternative perspective of Chinese international students. Journal of International Students, 10(2), 539-545. DOI: 10.32674/jis.v10i2.958

James, N. (2018). Using narrative inquiry to explore the experience of one ethnically diverse ESL nursing student. Teaching and Learning in Nursing, 13(1), 35-40. DOI: 10.1016/j.teln.2017.08.002

Jing, X., Gosh, R., Sun, Z., \& Liu, Q. (2020). Mapping global research related to international students: A scientometric review. Higher Education, 80, 415433. DOI: $10.1007 / \mathrm{s} 10734-019-00489-\mathrm{y}$

Laufer, M., \& Gorup, M. (2019). The invisible others: Stories of international doctoral student dropout. Higher Education, 78, 165-181. DOI: $10.1007 / \mathrm{s} 10734-018-0337$

Lee, D. (2020). Hong Kong third wave: With Covid-19 upending daily life, residents at greater risk of mental health problems, charity warn. Diakses tanggal 21 Agustus 2020, https://www.scmp.com/news/hongkong/society/article/3094695/hong-kong-third-wave-covid-19-upendingdaily-life-residents

Lim, N. (2016). Cultural differences in emotion: Differences in emotional arousal level between the East and the West. Integrative Medicine Research, 5(2), 105-109. DOI: 10.1016/j.imr.2016.03.004

Ma, T., Heywood, A., \& MacIntyre, C. R. (2020). Travel health risk perception of Chinese international students in Australia - Implication of Covid-19. Infection, Disease \& Health, 25(3), 197-204. DOI: 10.1016/j.idh.2020.03.002

Mechili, E. A., Saliaj, A., Kamberi, F., Girvalaki, C., Peto, E., Patelarou, A. E., Bucaj, J., \& Patelarou, E. (2020). Is the mental health of the young students and their family members affected during the quarantine period? Evidence from the COVID-19 pandemic in Albania. Journal of Psychiatric and Mental Health Nursing. Terbit pertama online (hlm. 1-9). DOI: 10.1111/JPM.12672

Mostafa, H., \& Lim, Y. (2020). Examining the relationship between motivation and resilience in different international students group attending U.S. universities. Journal of International Students, 10(2), 306-319. DOI: $10.32674 /$ jis.v10i2.603 
Nieto, A. (2016). Essential e-mentors' characteristics for mentoring online doctoral dissertations: Faculty views. Journal of Psychological Issues in Organizational Culture, 6(4), 35-68. DOI: 10.1002/jpoc.21204

Schreiber, J. B., \& Asner-Self, K. (2011). Educational research: The interrelationship of questions, sampling, design, and analysis. Hoboken, NJ: John Wiley \& Sons.

The Government of the Hong Kong Special Administrative Region. (2020). Situation on public hospitals and confirmed cases. Diakses tanggal 14 Oktober 2020, https://www.coronavirus.gov.hk/eng/index.html

Webster, L., \& Mertova, P. (2007). Using narrative inquiry as a research method: An introduction to using critical event narrative analysis in research on learning and teaching. London: Routledge.

Widodo, H. P. (2014). Methodological considerations in interview data transcription. International Journal of Innovation in English Language Teaching and Research, 3(1), 101-109.

\section{BIOGRAFI SINGKAT PENULIS [NOTES ON CONTRIBUTORS]}

Suprihatin (Kehok) adalah dosen di Program Studi Pendidikan Khusus, Fakultas Ilmu Pendidikan, Universitas Negeri Jakarta. Minat penelitian penulis dalam bidang pendidikan calon guru, autisme dan pendidikan inklusif. Email: kehoksuprihatin@gmail.com

Suprihatin (Kehok) is a teacher educator in the Department of Special Education at the Faculty of Education, Universitas Negeri Jakarta. Her research interests are in preservice teacher education, autism, and inclusive education. Email: kehoksuprihatin@gmail.com

Lilik Istiqomah mengajar bahasa Inggris dan penerjemahan pada Program Studi Pendidikan Bahasa Inggris, IAIN Surakarta, Indonesia. Lilik menekuni bidang riset seperti linguistik terapan, penerjemahan, penerjemahan lisan dan penerjemahan audio visual. Email: mdcorp100@gmail.com.

Lilik Istiqomah lectures on English language and translation studies in the Department of English Education of IAIN Surakarta based in Central Java, Indonesia. Her research interests include applied linguistics, translation, interpreting, and subtitling. Email: mdcorp100@gmail.com.

Rini Intansari Meilani saat ini mengajar bahasa Inggris untuk ekonomi dan bisnis di Universitas Pendidikan Indonesia. Minat riset penulis mencakup pengajaran bahasa Inggris untuk tujuan khusus, kognisi guru, desain mata kuliah, pengembangan bahan ajar dan metode penelitian. Email: intanmusthafa@upi.edu

Rini Intansari Meilani currently teaches English for Economics and Business at Universitas Pendidikan Indonesia. Her research interests lie in teaching English for Specific Purposes, teacher cognition, instructional design, language materials development, and research methodology. Email: intanmusthafa@upi.edu 
Khoiriyah (penulis korespondensi) adalah dosen di Fakultas Tarbiyah dan Ilmu Kependidikan (FTIK), Institut Agama Islam Negeri (IAIN) Jember, Indonesia. Bidang kajian riset penulis adalah pengembangan profesi guru dan pengembangan bahan ajar. Email: khoiriyah.iain@gmail.com

Khoiriyah (corresponding author) is a faculty member at the Faculty of Education at IAIN Jember, Indonesia. Her research areas include teacher professional development and language materials development. Email: khoiriyah.iain@gmail.com 